\title{
FACETS OF FEMALE EMANSIPATION IN LIFE AND CREATION OF N.D. KHVOSHCHINSKAYA
}

\author{
Pogrebnaya V. L.
}

\section{INTRODUCTION}

In Russian literature of the second half of the 20th century, a special place belongs to Nadezhda Dmitrievna Khvoshchinskaya (1824-1889), whose work is of undoubted interest to the modern reader. The heritage of N.D. Khvoshchinskaya is extensive and multifaceted. She is the author of eight large novels, twenty-two short stories, numerous essays, plays and short stories, poems, literary critical articles, and translations from French and Italian. In the pre-revolutionary period, her works were included into three collected works. One of them was introduced during her lifetime in 1859-1866. Then her works were published in two posthumous volumes in 1892 - and in 1912-1913, as well as in a fourvolume collection of her short stories in 1881.

Unfortunately, we have to admit that today Khvoshchinskaya's oeuvre is almost forgotten. The lion's share of her creations can be found only in publications of the nineteenth and early twentieth century. M. Goryachkina published selected works of Khvoshchinskaya under the general title "Tales and Stories" twice (Moscow, 1963; Moscow, 1984" in the Soviet time period. One of the writer's novels, named "Date," was included in the collection "Date: Prose of Russian Writers of the 60-80s of the 19th Century" (Moscow, 1987) ${ }^{2}$, compiled by V. Uchenova. None of Khvoshchinskaya's novels, such as "Meeting", "Ursa Major", "Recent time" and others were very popular among readers of the 19th century and they were not reprinted in the following time.

The lack of attention to the writer seems to us a clear misunderstanding. It is so because her multifaceted work was of exceptional importance in Russian literature of the second half of the

\footnotetext{
${ }^{1}$ Хвощинская Н.Д. Повести и рассказы / Сост. М.С. Горячкина. Москва : Гослитиздат, 1963. 512 с.; Хвощинская Н.Д. Повести и рассказы / Сост. М.С. Горячкина. Москва : Московский рабочий, 1984. 381 с.

${ }^{2}$ Свидание: Проза русских писательниц 60-80-х годов XIX века / Сост., авт. вступ. ст. и примеч. В. Учёнова. Москва : Современник, 1987. 509 с.
} 
nineteenth century as it was recognized by critics of various directions. Khvoshchinskaya raised a number of universal problems in her works, including the problem of the emancipation of a female personality. Khvoshchinskaya's oeuvre should be studied and should be appreciated in our time.

Considering the background of many reviews and reviews on Khvoshchinskaya's works, where a general assessment of her work was given, and the place of the writer in the ideological and political struggle of that time is determined. Several works, dedicated to the analysis of the creative manner of the writer to the identification of her attitude to female emancipation, are highlighted. Large article by P. Boborykin, named "Fiction belletrists of the old school,"3 articles of K. Arsenyev, combined and published as a large chapter in the first volume of "Critical Studies in Russian Literature," 4 and articles by M. Tsebrikova ${ }^{5}$ are among them.A new word about Khvoshchinskaya can be considered the work of E. Koltonovskaya, who devoted one of the chapters of the book "Women's Silhouettes (Writers and Actresses)" (St. Petersburg, 1912) to the work of this writer. Koltonovsky defines specific "female" features of Khvoshchinskaya's work after P. Boborykin and M. Tsebrikova. In post-revolutionary literary criticism, the creativity of Khvoshchinskaya was paid very little attention to. A.I. Beletskiy was among the few researchers, who were studying it. An academician A.I. Beletskiy highly appreciated the personality of Khvoshchinskaya. He intended to write a work devoted to the creation of this writer, as it was indicated in the master's thesis "Episode from the History of Russian Romanticism. Russian writers of 1830-1860" (Kharkov, 1919). ${ }^{7}$ Unfortunately, this intention has not been realized. A high appreciation of the writer's work

3 Б.Д.П. [Боборыкин П.Д.] Беллетристы старой школы (В. Крестовскийпсевдоним) Слово. 1879. № 7. Отд. II. С. 1-52.

${ }^{4}$ Арсеньев К.К. В. Крестовский (псевдоним). Арсеньев К.К. Критические этюды по русской литературе. В двух томах. Т.1. Санкт-Петербург : Типография М.М. Стасюлевича, 1888. С. 255-350.

5 Арсеньев К.К. В. Крестовский (псевдоним). Арсеньев К.К. Критические этюды по русской литературе. В двух томах. Т.1. Санкт-Петербург : Типография М.М. Стасюлевича, 1888. С. 255-350.

${ }^{6}$ Колтоновская Е.А. Женские силуэты (писательницы и артистки). СанктПетербург : Типо-лит. Акционерного Общества «Самообразование», 1912. С. $68-80$.

7 Белецкий А. И. Эпизод из истории русского романтизма. Русские писательницы 1830-1860 гг. I-V. Харьков, 1919. Отдел рукописей Института литературы НАН Украины, фонд 162, ед. сб. 519. 
was given by A.I. Beletskiy in the article "Turgenev and Russian Writers of $1830-1860^{\prime \prime}$, where the scientist suggests the influence of the artistic images of emancipated women created by Khvoshchinskaya on the work of I.S. Turgenev. The writer in the novel "Phrases" ("Village History") (1855) introduces a completely new type of woman for Russian literature who chooses "phrases" to demonstrate her emancipation, not backed up by any deeds. Turgenev will show this type of women in "Fathers and Sons" (Kukshina), "Two Friends" (Zadneprovskaya).

The scientist noted the innovation of Khvoshchinsky in creating the image of the "new woman". A.I. Beletskiy's point of view that main character of "the Krestovskiy and Khvoshchinskaya are already on the stage, which is next to Elena Stakhova and other new women"seems to us very productive, because in this case the pioneer in depicting the problems of female emancipation is not a male writer. As it is generally accepted there is still an assertion that such "pioneerswas a" are not M.L. Mikhailov, N.G. Chernyshevsky, I.S. Turgenev, but a womanwriter. It should be noted that Khvoshchinskaya is almost the only writer of the second half of the XIX century, whose work was dedicated to the special section in the academic "History of Russian literature"10. A.P. Mogilyanskiy, who wrote this section, paid attention to another writer, named Sofya Dmitrievna Hvoshchinskaya, who was a sister of Nadezhda Dmitrievna. These sisters were the only women among the numerous Russian writers, who were included into literary discourse by scholars. Scholars proved their special position and popularity, considering men's general inattention to female creativity. Literary gender studies have only appeared at the end of the twentieth century.

The attempts in order to determine the features of the "female" points of view in the works of Russian writers, including Khvoshchinskaya, were already made in the twentieth century.

The works of P. Boborykin, M. Tsebrikova, E. Koltonovskaya were previously mentioned in this article. It should be noted that modern foreign researchers consider the work of Khvoshchinskaya as fertile

8 Белецкий А.И. Тургенев и русские писательницы 1830-1860-х годов Білецький О. Зібрання пращь у п'яти томах. Т. 4. Київ : Наукова думка, 1966. C. 273-305.

${ }^{8}$ Белецкий А.И. Тургенев и русские писательницы 1830-1860-х годов. С. 302.

8 Могилянский А.П. Н.Д. и С.Д. Хвощинские. История русской литературы. В 10-ти тт. / под ред. М.П. Алексеева, Н.Ф. Бельчикова, В.А. Десницкого, А.А. Суркова. Т. 9, ч. 2. Москва, Ленинград: Изд-во АН CCCP, 1956. C. 228-237. 
ground for the study of gender technologies. So, Arya Rosenholm in the article "Her" and "stranger" in the concept of "educated woman" and "The Boarding School Girl" by N.D. Khvoshchinskaya"9 proves that the text of this story can be considered as "double", since it also reflects the male discourse of the" female issue "and the female one itself as well. Considering this, we must add that many other works of the writer can be considered from this point of view.

We can entitle the studies of O. Krenzholek ${ }^{10}$, E. Stroganova ${ }^{11}$, and A. Tyminskiy ${ }^{12}$ among modern works about N.D. Khvoshchinskaya. The problems of the typology of female images, the evolution of the image of the "new woman", the origin of irony in Khvoshchinskaya's work are not well investigated. Of particular note is the consideration of the specifics of the writer's relationship to female emancipation, which is reflected in her artistic work. In her novels and short stories, the writer touches on a number of problems associated with changing the role and place of women in the family and society depicts various facets of emancipation, which will be discussed in our study.

\section{N.D. Khvoshchinskaya served the cause of emancipation „by her own history as a human and a writer"}

There is an internal connection between the writer's work and her life, especially her education, her social circle and interests. For the most part of her life Khvoshchinskaya lived in Ryazan'. From the point of view of the provincial society, Khvoshchinskaya was engaged in "men's" affairs and she had masculine habits. She was able to defend her opinion, which was allowed mainly for men. She also smoked, did literary work and published her works in popular capital's magazines.

\footnotetext{
${ }^{9}$ Розенхольм А. «Своё» и «чужое» в концепции «образованная женщина» и «Пансионерка» Н.Д. Хвощинской «Своё» и «чужое»в литературе и культуре: Studia Russica helsingiensia et Tartuensia. № 4. Tарту: Tartu University Press, 1995. C. 143-166.

${ }^{10}$ Кренжолек О. Проблемы литературной позиции Н.Д. Хвощинской 18401860-х годов: Дис. ... канд. филолог. наук : 10.01.01. Москва, 1986. 160 с.

11 Строганова Е.Н. По поводу неудобного псевдонима. Надежда Хвощинская, она же В. Крестовский. Классики и современницыь: Гендерные реалии в истории русской литературы XIX века. Москва : Литфакт, 2019. C. 54-62; Строганова Е.Н. Портрет писательницы в некрологе: Отклики на смерть Н.Д. Хвощинской. Классики и современницы: Гендерные реалии в истории русской литературы ХІХ века. Москва : Литфакт, 2019. С. 63-76.

12 Тыминский А.И. Поэтика прозы Н.Д. Хвощинской: Дис. ... канд. филолог. наук: 10.01.01. Москва, 1997. 212 с.
} 
All this shocked others. V. Semevskiy was obviously right, claiming that ,a well-known part of Ryazan's society considered her almost crazy." ${ }^{13}$ Describing the situation of a developed woman in the province in the 1950s, K. Arsenyev wrote: "In Petersburg and Moscow, an educated woman, who shared the interests of educated men, was not unique at that time. In the province, she was still pointing with finger at. It was difficult for her to find herself among equal people and surround herself with the same equal people."

Above all, Khvaschinskaya proved the need to emancipate women not only by her creative work, but also by her lifestyle. The family of the writer lived in need. So she made money by literary work, helped his father in the service, made papers, drawings and letters for him. It must be noted that many characters of Khvoshchinskaya's works in literature already assisted their parents. For example, Anna Mikhailovna from the story, which is entitled the same name, and Kateryna Bagryanskaya from the novel "Ursa Major" "The Big Dipper" and others.

It is well-known that Khvoshchinskaya was strikingly different from secular ladies, because she was inclined to inward, spiritual life, and but not to external, ceremonial life. Social entertainment did not interest her. Sincerity and depth, naturalness, humanity and readability made the girl unlike any other. Praskovya Khvoshchinskaya wrote that her sister was ,alien to all lies and pretense."14

The writer's contemporaries correctly considered that N.D. Khvoshchinskaya's main merit was the creation of complete gallery of female characters and the problem of emancipation of a female personality. A. Nalimov noted that Nadezhda Dmitrievna served the cause of emancipation „by her own history, as a man and a writer."

Indeed, Nadezhda Khvoshchinskaya, like Avdot'ya Panayeva, and Marko Vovchok, and other female authors, took a step forward in the emancipation of women not only with their creativity, but also with their own lives. The biographies of these women prepared readers for the perception of ,women's literature.”

13 Семевский В.И. Н.Д. Хвощинская-Зайончковская (В. Крестовскийпсевдоним). Русская мыслль. 1890. № 10. С. 55.

13 Арсеньев К.К. В. Крестовский (псевдоним). С. 288.

${ }^{14}$ Крестовский В. (псевдоним) Собрание сочинений в пяти томах. - СанктПетербург : Издание А. С. Суворина, 1892. Т. 1. С. ХІІ.

${ }^{15}$ Налимов А. Русская писательница-пионерка. Ежемесячные сочинения. 1901. № 5. C. 29. 
In April 1883, the admirers of Khvoshchinskaya's talent presented an address under which there were 731 signatures in order to honor the anniversary of her literary activity. M. Tsebrikov, N. Shelgunov, M.E. Saltykov-Shchedrin, I. Repin, I. Kramskaya, A. Rubinstein and other major figures in Russian culture were among the signatories.

M. Tsebrikova took part in the compilation of this address. She cited it in her article "Essay on the life of N.D. KhvoshchinskayaZayonchkovskaya." The address noted the contribution of the writer to the emancipation of the Russian woman. It stated: "You are one of the first, who voted for the right of women to become participants in the general movement. And you are one of the first, who gave a lot of true and artistic pictures of women's struggle and suffering, with a deep understanding of the female heart. If the success of this struggle, although to some extent, could be considered provided, it was only because there were women who, like you, were able to show that the common activity was their business. You expressed not only the grief of the female destiny, but also the deep grief of the civil one, when you wrote in Katerina's words: “... and here, apart from everything, look, be silent, tear, bounded by hand and foot; cry uselessly, until there are enough tears, hand out pennies, if there are any, console with phrases if you have enough conscience. And in conclusion, don't dare to say that it torments you: it's not your business!" ${ }^{16}$ Khvoshchinskaya set forth her views on the emancipation of women in an extensive letter to a friend from Ryazan on June 5, 1865. It is according to the old style. She wrote: "The freedom of a woman, in my opinion, is her activity, and it begins with the ability to sew a patch and knead a teapot. If you can do more, then do more, even write treatises, like Mill's wife, just do it, just do it, but don't phrase under a cigarette." ${ }^{, 17}$

It should be noted that Nadezhda Dmitrievna's understanding of the "women's issue" was somewhat different from the ideas of revolutionary democrats and populists. The writer also believed that a woman should have equal rights with a man to education, work, and participation in public life. However, she never examined a woman in isolation from her family. The democrats' calls to create a utilitarian scheme of a rational female personality she viewed as far-fetched and non-vital ones. She "debunk" them in the novel "Boarding school girl", in the novel "Ursa

${ }^{16}$ Цебрикова М. Очерк жизни Н.Д. Хвощинской-Зайончковской. С. 36.

17 Cited from: Семевский В.И. Н.Д. Хвощинская-Зайончковская (В. Крестовский-псевдоним). С. 82. 
Major", in the essay "The Family and the School" ("The Teacher") and other works.

The ideal heroines of Khvoshchinskaya do not abandon their parents, husbands, and children. M. Tsebrikova recalled: "... Nadezhda Dmitrievna did not consider a woman's feat as a dropping of everything and sacrificing to her beloved person. This feat often leads to slavery of a woman; it happens that it is caused not by selflessness, but by temperament, and then the chosen one of the heart then has to pay bitterly for it." 18

Khvoshchinsky was not an adherent of the utilitarian rationally realistic canon, which completely rejected womanhood in a woman. V. Gorlenko, who knew the writer well in her last years of her life, recalled: "N.D., who created so many beautiful female characters, so deeply devoted to true enlightenment, loved to see a woman with all her own characteristics in a woman, and she could hardly endure asexual creatures ... She thought that the desire to be like a man speaks little in favor of independence women ..."19

\section{The type of ,a new woman" in the work of N.D. Khvoshchinskaya}

The "approaches" to the problem of female emancipation can be found already in the lyrics and early prose of ND Khvoshchinskaya. In her early lyrics, the theme of a suffering female soul in the midst of an alien light was outlined. The same motives are preserved in the first prose work of the writer, the novel "Anna Mikhaylovna" (1849), published in "Domestic Notes" in 1850 under the pseudonym of V. Krestovskiy. ${ }^{20}$ The story is innovative in terms of posing in it the problems of emancipation of the female personality. If we recall that the articles of M.L. Mikhaylova such as "Paris Letters", "Women, Their Education and Significance in the Family and Society", "Women at the

\footnotetext{
${ }^{18}$ Цебрикова М. Очерк жизни Н.Д. Хвощинской-Зайончковской. С. 18.

19 Горленко В. Крестовский-псевдоним (Воспоминание). Русский архив. 1897. № 4. C. 660.

${ }^{20}$ When publishing his lyrical works, Khvoshchinskaya did not use a pseudonym. For the first time, V. Krestovskiy's pseudonym was used by the writer in the publication of Anna Mikhaylovna. She did not refuse him even when other Krestovskiy appeared in the literature - V. Krestovskiy, author of the novel „The Petersburg Slums", V. Krestovskiy - playwright, M. Krestovskaya, author of the novels „Artist”, „Early Thunderstorms”. After learning about it, N.D. Khvoshchinskaya began to subscribe to „V. Krestovskiy nickname. She signed her critical articles with other aliases - V. Porechnikov, N., V.K., N.D. Exalted. Note that all aliases are male.
} 
University", "John Stuart Mill on the Emancipation of Women", calling for a change in the society' attitude and, especially, men to women, towards changes in the system of female upbringing and education, appeared in 1858-1860. But N.G. Chernyshevskiy's novel „What to do?” was written in 1863; therefore it becomes obvious that Khvoshchinskaya was one of the first almost a decade earlier than Mikhaiylov and Chernyshevskiy, who spoke about the imperfection of female education and the narrow views of girls graduated from boarding schools, about family despotism and the tragic fate of a thinking female person, who had to rotate in a society, where intrigue, idle talk, parasitism, lack of spirituality. The writer was one of the first to speak about the need for girls to do useful work and work. The plot of the first story of N.D. Khvoshchinskaya is simple. The main character, Anna Mikhaylovna Topilina, after the death of her beloved father, was in the family of her uncle. Despite the fact that the girl was not under his guardianship as a poor orphan, but, on the contrary, her uncle's family lived on her dowry. She was a victim of intrigue and gossip of the provincial elite. Moreover, she was forced to leave her relatives' house. Anna Mikhaylovna lost her fortune, good name, position in the world. Novels and stories written by Khvoshchinskaya in 1853-1858 such as the trilogy "The Province in the Old Years", published in1853-1856, had much in common with the problems from the novel "Anna Mikhaylovna". They were similar to this story in compositional and stylistic devices. This trilogy included the novels "Free Time", "Who Was Satisfied?", "The Last Action of the Comedy"), the novel "Test" (1854), the story "Phrases" ("Village History"), published in 1855, and the essay "Old Mountain" (1858).

It should be noted that in most of these works the problem of female emancipation is not explicitly stated, as in Anna Mikhailovna, but it exists implicitly, as the writer continues to worry about the tragic fate of girls who cannot escape from family and social oppression. Khvoshchinskaya shows many forms of oppression of a woman's freedom, imposing generally accepted false opinions on her, lack of a good education, marriage of convenience.

The problem of female emancipation was raised by the writer in the novel "Phrases" ("Village History"). The innovation of Khvoshchinskaya was to have showed Olga Grigoryevna as an energetic girl, trying to change Khotnitskiy, who was chosen by her, for the better. In her novels simplicity, ease, sincerity, desire for useful activities, moral independence of the character are opposed to artificiality, pretense, unnaturalness, phrasing, inactivity of Praskovya Alexandrovna 
Zalesskaya, an aristocrat who came to her real estate. The character of Zalesskaya is revealed in her actions, actions that contradict her "phrases". The idea of this story does not lie on the surface of narration; it is hidden in actions and characters, which testifies to the psychological skill in writing of Khvoshchinskaya. The conversations of Praskovia Aleksandrovna about selflessness, self-sacrifice for a great purpose turned out to be nothing more than phrases.

In the 60-80s, N.D. Khvoshchinskaya was developing a type of "new woman" in the novels "Meeting" (1860), "Recent" (1865), "Ursa Major" (1870-1871), "The Past" (1878), in the novel "Boarding School Girl" (1861), in essays „Ridneva” (1875), „Teacher” („Family and School”) (1879-1880), ,Vera” (1876).

The image of Nastasya Mikhailovna (novel "Recent" (1865) can be considered as a "transitional" way from passive, slaughtered characters to anactive, active, "new" image. This girl is not a fighter by nature. Unlike passive character, Nastasia Mikhailovna strives for knowledge and work, is well aware of her position in the family and society and wants to change it, but does not find strength and opportunity.

"The decisive factor in her formation and development for Nastasia Mikhaylovna was communication with a male mentor. You can build such a chain of "developers" such as gymnasium students, an official visitor Zatsepin, an architect Maleev, an official Borovitskiy.

P. Tkachev was absolutely right when he claimed that a girl in the position of Nastasiya Mikhaylovna had two options s to die physically or die pshycologically. ${ }^{21}$ The character first dies "psychologically", killing all her heart feelings and then physically. Moreover, her real death is very reminiscent of the Lisa Bakhareva's death, which is the character of N.S. Leskov's novel "Nowhere" and Evgeniy Bazarov, who is the character of I.S. Turgenev's novel "Fathers and Sons". "Nastasia Mikhaylovna simply died, having caught a cold, having been ill, and not having healed on time.",22 wrote Khvoshchinskaya. This "not healed on time" raises the idea that the character has not valued her life too much.

The transition to the "new" characters can be considered Alexandra Akhtarovskaya's image from the novel "Meeting". It should be noted that she was already an emancipated woman; however, her emancipation

${ }^{21}$ Никитин П. [Ткачёв П.Н.] Гнилые корни. Дело. 1880. № 3. С. 295.
${ }^{22}$ Крестовский В. (псевдоним) Собрание сочинений в пяти томах. Т. 4. С. 143. 
was "innate", spontaneous, not connected with the democratic ideas of that time. Akhtarovskaya was a strong nature.

Being barely married, she was not afraid to leave her wretched husband, drunkard, rowdy and tyrant at her seventeen. Having abandoned her husband, she severed not only relations with him, but also relations with the world, since this act met with the condemnation of mothers, aunts, and mentors. Akhtarovskaya's calm, restraint, equanimity, taciturnity are contrasted in the novel of Lyudmila Panteleeva's talkativeness and enthusiasm, which speaks a lot, out of place and out of place, and, most often, loudly and cheekily. Bing a deep and harmonious person, Akhtarovskaya loved nature and music, what could not be said about Lyudmila. The following detail should be given as some examples Lyudmila did not like the old garden, the flowers growing in it, and Alexandra Grigoryevna admired it and liked to walk along his alleys. Akhtarovskaya, who did not claim like Lyudmila about her role of a poetess, a broadcaster of new ideas, felt very subtly and knew how to appreciate beauty. She was more intelligent and witty than Panteleeva. She correctly and accurately marked many events. By the 60 s of the nineteenth century Khvoshchinskaya had already mastered skills of a writer and psychologist. She deeply and comprehensively revealed the complex structure of female characters. One of the vivid images, belonging to the active and strong type of women, was Liolen'ka's image, Elena Gosteva's prototype in the novel „Boarding School Girl" (1861). The character of the story lived in a provincial town in the family of a poor and having many children official. The girl's neighbor, Veretitsin, a former teacher who was exiled to this city for writing liberal poems, exhausted from melancholy, half-joking, convinced Lio len'ka that she was teaching nonsense to please her parents. The girl, under his influence, failed exams at Boarding school and left for an aunt in Petersburg.

Veretitsyn met with his neighbor in the Hermitage eight years later, where the latter copied the paintings. He was struck by the changes that had occurred in the girl's life. She became an educated and practical business person. He was a very energetic and self-confident, strongwilled and purposeful lady.

N.G. Chernyshevskiy's novel "What to do?" was published two years later after the release of "Boarding School Girl" by Khvoshchinskaya. It dramatically affected minds not only of the youth of the 60-80s of the nineteenth century. It also dramatically affected many subsequent generations of young men and women seeking independence. 
The common theme of Chernyshevskiy's novels and the stories of Khvoshchinskaya are beyond of doubt. O. Krenzholek believes that "the novella "Boarding School Girl" (1861) with emancipator tendencies in the spirit of the post-reform era is largely preceded by Chernyshevskiy's novel "What to do?"23.

It must be noted that the influence of the male leader on the woman was a prerequisite and one of the motives of male democratic literature. V. Sleptsov, N. Chernyshevskiy, N. Bazhin, N. Pomyalovskiy depicted men as the "developers" of women. The writer destroys the myth of the leading role of the men in the development of the women. He shows Veretitsyn as an inconsistent and weak person. Veretitsyn, as a developer, gives Liolen'ka only the first impetus to its development.

Perhaps, the first unhappy love experience or the example of a mother, who was her husband's slave, would affect the fact that Liolen'ka would reject love, friendship, generally any feelings in the name of work, knowledge and work. Liolen'ka embodied a completely new female image of the "ordinary egoist" in Russian literature as V. Ostrogorskiy ${ }^{24}$ defined. On the one hand, it was a completely new female image of a feminist woman, who has a number of positive qualities such as activity, efficiency, a desire for education and work. But on the other hand, a feminist woman had such negative qualities as heartlessness, ingratitude, insensibility. This was a predatory type of a woman.

Khvoshchinskaya portrays Liolen'ka as a very pretty and attractive girl, who voluntarily refused to marry for the sake of principle. She wrote: "I realized what a yoke of love is. How it makes you look through the eyes of another person and disappear before the will of anyone. I will never fall in love. It is stupid." "We must remark that the heroine does not say "nobody", but says "once, stupidly". That is, the sensory principle is completely suppressed by rational principle in Liolen'ka. Love, marriage, family, sensuality, emotional dependence on someone else was considered by Liolen'ka as slavery. The girl wanted to be alone, to be free. A. Rosenholm correctly noted a certain discrepancy between

23 Кренжолек О. Проблемы литературной позиции Н.Д. Хвощинской 18401860-х годов. С. 6.

24 Острогорский В.П. Этюды о русских женщинах. Женское образование. 1880. № 6-7. С. 411.

25 Крестовский В. (псевдоним) Собрание сочинений в пяти томах. Т. 2. C. 495 . 
such aspirations and the program of revolutionary democrats: „The denial of marriage for the purpose of autonomy, however, distinguishes her from male contemporaries, who sought metaphysical solutions to the problems of their time." 26 According to the thoughts of revolutionary democrats, the woman was supposed to escape herself from slavery by means of a fictitious marriage. Liolen'ka did not have a fictitious marriage or other forms of marriage. It confirms the idea that Khvoshchinskaya is moving away from the male canon in her perception of the "new woman".

Since Liolen'ka's sensory sphere was completely undeveloped, she completely lacked a memory of the past, a desire to help parents or brothers and sisters. Liolen'ka forgot everything, because she considered her parents to be limited and cruel, vulgar and unspiritual people. But at the same time she considered herself to be the top of perfection. ${ }^{27}$

Sophia Khmelevskaya, who Veretitsyn loved, was the contrasting image to Liolen'ka (Elena Gosteva). This woman is meek, responsive, feminine, and capable of self-sacrifice for the happiness of others. In these two women, Khvoshchinskaya embodies the two most common female types: the "sweet" woman and the "educated" woman. It is A. Rosenholm's terminology. ${ }^{28}$

Whose part is Khvoshchinskaya on? In our point of view, Semevskiy answers this question quite correctly: "The author obviously does not consider normal one or another decision of two women to have life of a leader. But, apparently, he still prefers the self-sacrifice of one, who leads an independent and selfish life." 29 V. Semevskiy quoted N.D. Khvoshchinskaya's letter in his work. It was written by her to one of her friends: in 1865 „It is possible, as I have said in «Boarding School Girl", to throw stupid and cruel relatives, to abandon attachments, to sit down for work, but it will be half life, already one of these abnormal and

${ }^{26}$ Розенхольм А. «Своё» и «чужое» в концепции «образованная женщина» и «Пансионерка» Н.Д. Хвощинской С. 154.

${ }^{27}$ See for more details: Погребная В.Л. Антифеминистский дискурс повести Н.Д. Хвощинской «Пансионерка» Поетика художніх форм у сучасному сприйнятті: науковий збірник / ред. кол. : відп. ред. Силантьєва В.І. Одеса : Астропринт, 2012. С. 146-157.

${ }^{28}$ Розенхольм А. «Своё» и «чужое» в концепции «образованная женщина» и «Пансионерка» Н.Д. Хвощинской С. 155.

29 Семевский В.И. Н.Д. Хвощинская-Зайончковская (В. Крестовскийпсевдоним). С. 67. 
presenting their sorrows and its inconveniences. In my opinion, any gap is already sadness, inconvenience, frustration, but not the structure of life or society." ${ }^{, 30}$ The writer recognized the need not only for public service, but also for the personal happiness of every woman, which she understood as family happiness, as serving others. The independence of a woman, in point of Khvoshchinskaya's view, should not be mixed with her direct destiny. Her direct destiny was to be a mother, a sister, a wife, a daughter, etc. Elena Gosteva in "Booarding School Girl" refused her direct destiny. According to M. Tsebrikova, in this story Khvoshchinskaya "outlined the emerging type of female worker and career-aimed; she correctly guessed the nascent features of what can be called bureaucracy in women, who call themselves new women." ${ }^{31}$ M. Tsebrikova mentioned with reason about the importance of career. If the activities of the Turgenev main characters, for example Elena Stakhova and Marianna, were aimed at public service, then the activities of Liolen'ka had a completely different direction. She lived purely for herself.

The image of Katerina Bagryanskaya, the main character of N.D. Khvoshchinskaya's novel „Ursa Major” (1870-1871) is exact opposite to the image of Elena Guesteva. The image of Bagryanskaya, who considered her duty to serve people and bring benefits, was close and understandable to democratically minded youth. P. Kropotkin considered the image of Katerina to be vital and real. Moreover, at the beginning of the twentieth century he wrote comparing the heroine of Khvoshchinskaya with the "Turgenev's girl”: “... Katya stands higher, more vital, more fully depicted than Turgenev's Natasha or even him. She was disgusted with all the talks about heroic exploits, which "future circumstances" prevented future heroes from doing. She took on a task incomparably smaller: she became a teacher in a village school and tried to bring into the darkness of the village the light of higher ideals and hopes for a better future." 32

The writers of the democratic direction showed women decisively breaking family chains, engaged in labor and social activities, which completely replaced their family in their works. It should be noted that

${ }^{30}$ Cited from: Семевский В.И. Н.Д. Хвощинская-Зайончковская (В. Крестовский-псевдоним). С. 67-68.

${ }^{31}$ Цебрикова М. В память В. Крестовского-псевдонима. С.2.

32 Кропоткин П. Идеалы и действительность в русской литературе. СанктПетербург : Издание Товарищества «Знание», 1907. С. 200. 
such a difficult step as the departure from parents was portrayed by them not entirely believable. N. Strakhov in his article «Happy People» quite rightly notes that "new people", including Vera Pavlovna, the heroine of the novel "What to do?" lives in such an isolated space, "they are in some kind of exceptional position, obviously very convenient for their well-being. Namely, they have no children and almost no fathers and mothers".

Perhaps it was difficult for Katerina Bagrianskaya to leave her father, because she was brought up, surrounded by his care and love. Family affection, love support a person in the most difficult moments of one's life from the point of view of many Russian writers of the second half of the twentieth century as N.S. Leskova, I.A. Goncharova, A.F. Pisemskogiy, L.N. Tolstoy and others. Khvoshchinskaya was of the same opinion.

Katerina was emancipated in the best sense of the word. She was not limited by words about the usefulness of activities, but she worked with her father. She did not shun of domestic duties, sow men's shirts under the order. The girl did not even have the idea that she was implementing any ideas. She was governed not by theory, but by the love to her neighbor. That is why she was the harmonious and natural person. Belonging to a cast of provincial aristocracy, Katerina realized her emptiness and vulgarity. That is why she was a rare guest at balls, parties, dinners. The origins of the image of Katerina Bagrianskaya should be sought in the early lyrics of N.D. Khvoshchinskaya. Her short stories and novels of the 50-60s, where motives of condemning the emptiness and bustle of social life, has already appeared those ideas and images outlined as central in the mature period of the writer's work. We can talk about the evolution of female images in the works of Khvoshchinskaya, in particular, about the evolution of the image of the "new woman". Katya Bagryanskaya is the most outstanding person in the chain of images of women that were created by the writer over forty years of literary activity. The image of Anna Mikhailovna, the character of Kvoshchinskaya's first story "Anna Mikhailovna" can be considered as the forerunner of Katerina's image. This is an active nature, helping his uncle's affairs, deep and self-sufficient. So the same qualities are

${ }^{33}$ Страхов Н. Счастливые люди. Страхов Н. Из истории литературного нигилизма. 1861-1865. Санкт-Петербург : Тип. Братьев Пантелеевых, 1890. C. 320 . 
inherited by Katerina. Their self-estimation, the desire to see an active person in beloved one, but not a "phraser," also makes women become closer. They are even similar in appearance. Khvoshchinskaya depicts them as the southern type of beauty. They had black braids, expressive eyes. They were hot- tempered and full of emotionality, passion and courage.

As the novel „Ursa Major” was written twenty years later, the novel "Anna Mikhailovna", of course, the image of the "new woman" could not, but changed. I Katerina's character has something that her predecessors did not have. Her desire to be useful to people, to take the path of labor and public service was exceptional.

The problems associated with the emancipation of the female personality were depicted in many of writers late works the such as: the novels "The Former" (1878) and "Duties" (1885-1886), the novels "Date" (1879) and "Farewell" (1884), a cycle of short stories and essays "Album. Groups and portraits" (1874-1877) and essays "In the Evening" (1876), "Family and School" or "Teacher" (1880), "Vera" (1876), "Blizzard" (1889).

The story „Teacher" was originally published in the journal «Domestic Notes» (1880, No. 4) under the title «Family and School». The main image of the story "Teacher" is twenty-four-year-old Zinaida Nikolaevna Terebeneva. She was the daughter of a hairdresser and laundress. Despite her social background, thanks to her abilities and talent, she graduated from gymnasium and the university. Khvoshchinskaya portrays the facts that really have existed in the 70-80s of the 19th century. In some cases, high education became available to girls from families of different families.

The story begins as the main character arrived as a teacher of school at the village after staying with children at home for seven years. All her thoughts were directed to the recollection about her beloved person, called Misha, who died of phthisis. Misha Ivanov, who believed in revolution, had a great influence on the teenage girl. He thought about the salvation of all humankind, but did not think about the closest people, his beloved girl, sister. Along with the excellent qualities of the "Narodniks" the desire to improve the world, the willingness to give their lives in the struggle for the happiness of mankind, Khvoshchinskaya shows their inferiority, which is expressed in rigidity in relation to the closest people, straightforwardness, «inflexibility», obstinacy. 
The scene of the last meeting between Misha and Zinaida Nikolaevna was dramatic on the characters' part. They loved each other. This whole scene is a tense dialogue between male and female characters. Michael insisted the girl to leave her mother and go with him "in the revolution". She sacrificed her love for him in the name of love for her mother. Zinaida Nikolaevna believed that she was fulfilling her duty, having remained with an elderly, sick mother in need of her help. The girl was convinced: "I can sacrifice myself, but I have no right to others... .", Misha spoke calmly, as if he was reading a textbook. He reproached Zinaida Nikolaevna that she "had changed people for people". ${ }^{35}$ The author's position coincides with the position of the main character," who believes that helping a particular person is more real and necessary than helping "humanity", since it consists of specific people. Misha Ivanov reproached Zinaida Nikolaevna for being soft-bodied. He said that she was as "heart in half, no candle, no poker." However, it is exactly this girl's ability not to fall into extremes, to see the general and the particular, to love all and everyone, which allows talking about her humanity, the flexibility of her mind, in contrast to her lover. Zinaida Nikolaevna was denied in teacher's place. Instead of her, an uneducated and callous person, an opponent of female education, received the appointment. The ending of the story is pessimistic. Her hopes for the opportunity to work for the benefit of the peasants and their children, hopes for ensuring the old age of the mother are crumbling. Being the girl, student rushed to the neck of her beloved teacher, weep. She would no longer study at this school, because the new teacher would only teach boys. Despite this ending, the story of Khvoshchinskaya made an optimistic impression on her contemporaries. V. Novakov, for example, believed that Zinaida Nikolaevna was «a new type of the Russian woman», so-called type of social or "worldly worker," 36 clearly demonstrating that in the female environment the moral and mental level has increased. Life circumstances prevented Zinaida Nikolaevna's plans from being realized, but her undertakings, impulses and thoughts left their mark on those students with whom she was engaged, on those

${ }^{34}$ Крестовский В. (псевдоним) Собрание сочинений в пяти томах. Т. 5. С. 184.

${ }^{35}$ Крестовский В. (псевдоним) Собрание сочинений в пяти томах. Т. 5. С. 185.

${ }^{35}$ Крестовский В. (псевдоним) Собрание сочинений в пяти томах. Т. 5. С. 185.

36 Новаков В. Женские типы в современной беллетристике. «Мирская труженица» (По поводу повести В. Крестовского «Семья и школа»). Женское образование. 1880. № 4-5. С. 187. 
peasants with whom she communicated. Even after leaving the village, the teacher will not remain idle. Such ,worldly toilers" who love their work and children will always be popular among people.

\section{Critique of pseudo-emancipation}

The merit of Khvoshchinskaya was to portray a special type of "emancipe"- women from high society, who were indifferent to social problems and work, but emancipated from the point of view of their attitude towards men, who considered themselves superior to men, who were able to "buy" husbands and lovers. None of the Russian writers had such a gallery of female facets of "emancipe-despot" and selfish women, who used the ideas of emancipation for the sake of fashion, for their own benefit. Moreover, these women were rich, they did not feel themselves to be dependent on society, relatives, because they, themselves, had reputation in society and money that allow them to understand emancipation as "freedom of morals", or licentiousness.

In practice the process of emancipation of a female personality „turned" to be of various facets. Some secular women perceived the ideas of emancipation in a distorted, false form. The behavior of these women expressed many "excesses". The protest was expressed in the loss of moral features. This „emancipation can be described as "spontaneous, ugly. The origin of this type is shown by Khvoshchinskaya in the image of Praskovia Aleksandrovna Zalesskaya, depicted in the story „Phrases” (,Village History”). It can be considered as a continuation of the images of Katerina Alexandrovna, Polina from the novel „Waiting for the best”, Lyudmila Andreevna from the novel „The Meeting”, Nadezhda Sergeevna from the novel „Recent”, Lydia Matveevna from the novel "Ursa Major", Varvara Pavlovna from the novel „Responsibilities”, Ganevich from the novel“" The Past”, m-me Munovskiy from the essay "Vera". Speaking of a pretentious vulgar emancipation, one cannot but mention Khvoshchinskaya's novel "Meeting" (1860), in which the image of Lyudmila Andreevna Panteleeva, poetess and "emancipe" is convex and vividly depicted. She lived in a village with her mother and sisters and led an unusual lifestyle for girls of that time, associated with writing and promoting fashionable ideas of emancipation.

Ludmila liked to pose, play, and talk about the role of women in society, their rights. She never talked about their responsibilities in front of family and in front of society. She was very wordy. The falsity, hypocrisy, 
unnatural character of the heroine, her desire to appear, to look but not to be a leading woman was skillfully debunked by a writer. ${ }^{37}$

The type of egoistic "emancipe" is deduced by Khvoshchinskaya in the novel "The Big Dipper". Lidia Matveevna Merezhnikov acted as a tyran and despot in the novel. Her husband, Andrei Verhovskiy, was a victim. This is emancipation from the inside out. The image of Lidia Matveevna, Verkhovsky's wife, is contrasting with the image of Catherine Bagryanskaya. If Catherine creates an atmosphere of harmony, light, warmth, and has an amazing ability to connect people. Lidia Matveevna is so sharp, rude, and despotic that she creates a heavy, gloomy atmosphere around her. The constant scenes with her husband and her children, the fainting, the hysterics of this woman make others feel tension and fear.

Images of provincial lionesses that chose the ideas of emancipation as a program of action because of the cold heart are found in almost of all novels of the writer of the 60-80s of the 19th century. The „Duties" novel (1885-1886) is not an exception in this regard. In the novel, the image of Barbara Kirinova is the most successful, vivid, and vital prototype. Guided by the cold heart, acting on a well-thought out plan, the elderly virgin Barbara Pavlovna, married 23-year-old Alexander Tarbov. Later, she would leave her unloved husband. She needed this marriage only to have his surname.

It is necessary to note another such characteristic feature. All vulgar "emancipes" in Khvoshchinskay 's works such as Lyudmila in „Meeting”, Lydia Matveevna in „Big Bear”, Nadezhda Sergeevna in „Recent”, Varvara Pavlovna in „Obligations” do not like nature. Varvara Pavlovna is angry observing swallows. She hates everything spiritualized and beautiful. Its cruelty is manifested even in relation to birds. She recalls with pleasure: „In Hyde Park all the birds were poisoned at the exhibition." ${ }^{38}$.The author states: „If she had a mask, she would have drowned it with her own hands! ${ }^{39}$ The novel for good reason is called

${ }^{37}$ See for more details: Погребная В.Л. Роман Н.Д. Хвощинской «Встреча» в контексте эмансипационного движения Филологические исследования: Международный сборник научных трудов. Вып. 2. Запорожье, Белгород : ЗЮИ МВС Украины, 2003. С. 217-224.

38 Крестовский В. (псевдоним) Собрание сочинений в пяти томах. Т. 5. C. 364.

39 Крестовский В. (псевдоним) Собрание сочинений в пяти томах. Т. 5. C. 340 . 
„Responsibilities.” The writer was deeply convinced that each person has not only rights, but also duties, debts to society and other people. All Varvara Pavlovnafather's life, Pavel Vasilyevich Kirinov, was the fulfillment of duties to a morally unscrupulous father, unloved wife, cruel and callous daughter, and peasants. His life is an example of sacrifice, Christian love for his neighbor.

Kirinov's daughter believed that she had no obligations to her father. Having beaten the old father, she took him to a farm. She had no obligations to her husband. In year after the birth of her daughter, she left her husband, because she thought that the lifestyle of the work of scientist did not correspond to her ideas about a luxurious life. She left her daughter with strangers and was not worried about her upbringing at all. Nevertheless, she believed that everyone around her had to serve her. Having squandered all her fortune, Varvara appeared to her father, reminding him about the duties to her daughter and granddaughter. The old man believed that it was necessary to help not the daughter-spender, but the unfortunate and destitute people. The novel ends with his words expressing both the program of his actions and his worldview: "Everyone will find a place and work for himself, if he has his own hunt. An extra one, who does not love anyone ... ." ${ }^{40}$ The images of Kirinov's father and daughter are contrasting, because the father embodies the ideal of serving people, and the daughter is the anti-ideal of pursuit of pleasures.

The image of Varvara Pavlovna is in to contrast the image of Anna Grigoryevna, the second wife of Kirinov. She did not speak in fashionable phrases about emancipation; she was emancipated in the best sense of the word, because she was comprehensively developed, educated, kind and hardworking. Anna Grigorievna had everything that was not in Barbara Pavlovna. It is femininity, grace, sacrifice, and love for others.

The emancipation of Varvara Pavlovna is ostentatious, pretense. The charater talked a lot about women's rights and women's labor. Fashionable women's issue was accepted by her, because she was carried away from boredom, from idleness. Social activity gave her the opportunity to attract the attention of youth. Her emancipation is an attempt to conveniently adapt to new conditions of life, but not an

\section{375 .}

40 Крестовский В. (псевдоним) Собрание сочинений в пяти томах. Т. 5. 
attempt to improve itself, to get equal rights to work and have education with men.

\section{CONCLUSIONS}

N.D. Khvoshchinskaya, whose work occupied the leading position in the nineteenth-century in women's literature, believed that women should have equal rights to education, to work, and to participate in public life with men, but she ad never considered a woman in isolation from her family.

The writer is rightly considered a connoisseur of female psychology. Her experience in creating a whole gallery of female characters is innovative. In the early lyrics of N.D. Khvoshchinskay and her stories and novels of the 1850-60s, there are motives to condemn the emptiness and bustle of secular life. This is the period to outline those ideas and images that will become central in the mature period of the writer's work. She is one of the first to create a number of vivid images of "new women" striving for useful activities, knowledge, and spiritual freedom. In her works, N.D. Khvoshchinskaya depicts those characters with special love, who have lived for others. We can enumerate them: Katerina in the novel "Ursa Major", Nastasia Mikhailovna in the novel "Recent", Zinaida Nikolaevna in the essay "Teacher", etc. In works written at different times, the idea that women's destiny cobynsists not only in serving society, an idea, a cause, but, above all, in serving others is expressed.

The plot of the novel about "new people" in male democratic literature, represented by such writers as V. Sleptsov, N. Bazhin, N. Chernyshevskiy and others, suggested various options for the characters to "leave" the parental home, as well as the obligatory patronage of a male developer, such as a friend, a teacher, a husband, etc.. The writer departs from these plot content and destroys the myth of the leading role of men in the development of women.

N.D. Hvoshchinskaya in her stories and novels depicts various poles of emancipation. The type of the "new woman" in her work is manifested in various ways. On one side this is the type of reasonably emancipated woman and on the other side this is the type of "ordinary egoist". For example, Liolen'ka's from the novel "Boarding School Girl". The writer also studies and depicts the type of vulgarly emancipated woman in her novels. The images of representatives of this type in the novels "Meeting", "Recent", "Ursa Major", "Responsibilities" are clearly outlined, painted in bright colors. Subtle 
irony helps the author to reveal the discrepancy between the "words" and deeds of the "emancipes", who were carried away by the fashionable "female issue" from idleness or for the sake of profit.

The writer observes that, unlike truly emancipated women who see their freedom, primarily in development, work, self-centered emancipators, they are spiritually undeveloped, callous, limited, do not value human affection and feelings, do not like children, even their own. They do not notice the beauty of nature, they dislike animals. The author intentionally depicts their falsity, hypocrisy, unnaturalness.

In each of her novels N.D. Hvoshchinskaya contrasts a working woman, emancipated in the best sense of the word, to an emancipator egoistic woman. The reception of contrast allows the writer to determine her female artistic ideal, her attitude to female emancipation.

Not all problems of N.D. Khvoshchinskaya works were finally resolved by researchers. A wide field of activity is open for scientists studying her works. They must be researched as in terms of discovering and studying texts unknown to the modern reader as in terms of rethinking of those already studied.

\section{SUMMARY}

The oeuvre of the undeservedly forgotten Russian writer of the second half of the 19th century N.D. Khvoshchinsky reflects the process of emancipation of the female personality. The behavior and lifestyle of Nadezhda Dmitrievna was reformatory, since she became a popular writer, published her many works in the capital's magazines, supported her family, and was able to defend her opinion. The writer was a supporter of sensible female emancipation.

The creation of whole gallery of female characters and types was faithfully considered by her contemporaries as N.D Khvoshchinskaya's main merit. She is one of the first to create a number of vivid images of "new women" striving for useful activities, knowledge, and spiritual freedom. In her works N.D. Khvoshchinskaya depicts those characters with special love, which live for others such as Katerina in the novel "Ursa Major", Nastasya Mikhailovna in the novel "Recent", Zinaida Nikolaevna in the essay "Teacher" and others. In works, written at different time, the idea that women's destiny consists not only in serving society, an idea, a cause, but, above all, in serving others, is expressed.

In her works N.D. Khvoshchinskaya manifests the type of the „new woman" in various facets. This is the type of reasonably emancipated 
woman and the type of "ordinary egoist". The writer studies in detail and depicts in an ironic manner the type of vulgarly emancipated woman.

N.D. Khvoshchinskaya creates the male novel about „new people”, destroys the myth of the mandatory ,departure" of the characters from the parental home, about the leading role of the men in the development of the women.

\section{REFERENCES}

1. Хвощинская Н.Д. Повести и рассказы / Сост. М.С. Горячкина. Москва : Гослитиздат, 1963. 512 с.

2. Хвощинская Н.Д. Повести и рассказы / Сост. М.С. Горячкина. Москва : Московский рабочий, 1984. 381 с.

3. Свидание: Проза русских писательниц 60-80-х годов XIX века / Сост., авт. вступ. ст. и примеч. В. Учёнова. Москва : Современник, 1987. 509 с.

4. Б.Д.П. [Боборыкин П.Д.] Беллетристы старой школы (В. Крестовский-псевдоним) Слово. 1879. № 7. Отд. ІІ. С. 1-52.

5. Арсеньев К.К. В. Крестовский (псевдоним). Арсеньев К.К. Критические этюды по русской литературе. В двух томах. Т. 1. Санкт-Петербург : Типография М.М. Стасюлевича, 1888. C. $255-350$.

6. Цебрикова М. Очерк жизни Н.Д. Хвощинской-Зайончковской. Мир божий. 1897. № 12. С. 1-40.

7. Цебрикова М. Художник-психолог (Романы и повести В. Крестовского-псевдонима). Образование. 1900. № 1. С. 17-34; № 2. C. 37-54.

8. Цебрикова М. В память В. Крестовского-псевдонима. Новости.1889. № 177. С. 2.

9. Колтоновская Е.А. Женские силуэты (писательницы и артистки). Санкт-Петербург : Типо-лит. Акционерного Общества «Самообразование», 1912. С. 68-80.

10.Белецкий А. И. Эпизод из истории русского романтизма. Русские писательницы 1830-1860 гг. I-V. Харьков, 1919. Отдел рукописей Института литературы НАН Украины, фонд 162, ед. сб. 519.

11.Белецкий А.И. Тургенев и русские писательницы 1830 1860-х годов Білецький О. Зібрання пращь у п'яти томах. Т. 4. Київ : Наукова думка, 1966. С. 273-305. 
12.Могилянский А.П. Н.Д. и С.Д. Хвощинские. История русской литературы. В 10-ти тт. / под ред. М.П. Алексеева, Н.Ф. Бельчикова, В.А. Десницкого, А.А. Суркова. Т. 9, ч. 2. Москва, Ленинград: Изд-во АН СССР, 1956. С. 228-237.

13. Розенхольм А. «Своё» и «чужое» в концепции «образованная женщина» и «Пансионерка» Н.Д. Хвощинской «Своё» $и$ «чужое» $в$ литературе и культуре: Studia Russica helsingiensia et Tartuensia. № 4. Тарту: Tartu University Press, 1995. C. 143-166.

14.Кренжолек О. Проблемы литературной позиции Н.Д. Хвощинской 1840-1860-х годов: Дис. ... канд. филолог. наук : 10.01.01. Москва, 1986. 160 с.

15.Строганова Е.Н. По поводу неудобного псевдонима. Надежда Хвощинская, она же В. Крестовский. Классики и современнищьл: Гендерные реалии в истории русской литературы XIX века. Москва : Литфакт, 2019. С. 54-62.

16.Строганова Е.Н. Портрет писательницы в некрологе: Отклики на смерть Н.Д. Хвощинской. Классики и современнищь: Гендерные реалии в истории русской литературы XIX века. Москва : Литфакт, 2019. С. 63-76.

17.Тыминский А.И. Поэтика прозы Н.Д. Хвощинской: Дис. ... канд. филолог. наук: 10.01.01. Москва, 1997. 212 с.

18.Семевский В.И. Н.Д. Хвощинская-Зайончковская (В. Крестовский-псевдоним). Русская мысль. 1890. №10. С.49-89.

19.Крестовский В. (псевдоним) Собрание сочинений в пяти томах. Санкт-Петербург : Издание А.С. Суворина, 1892.

20.Налимов А. Русская писательница-пионерка. Ежемесячные сочинения. 1901. № 5. С. 29-39; № 6. С. 125.

21.Горленко В. Крестовский-псевдоним (Воспоминание). Русский архив. 1897. № 4. С. 658-663.

22.Никитин П. [Ткачёв П.Н.] Гнилые корни. Дело. 1880. № 3. C. $283-324$.

23. Острогорский В.П. Этюды о русских женщинах. Женское образование. 1880. № 6-7. С. 315-330, 391-412.

24.Погребная В.Л. Антифеминистский дискурс повести Н.Д. Хвощинской «Пансионерка» Поетика художніх форм у сучасному сприйнятті: науковий збірник / ред. кол. : відп. ред. Силантьєва В.І. Одеса : Астропринт, 2012. С. 146-157.

25.Кропоткин П. Идеалы и действительность в русской литературе. Санкт-Петербург : Издание Товарищества «Знание», 1907. $368 \mathrm{c}$. 
26. Страхов Н. Счастливые люди. Страхов Н. Из истории литературного нигилизма. 1861-1865. Санкт-Петербург : Тип. Братьев Пантелеевых, 1890. С. 200-205.

27.Новаков В. Женские типы в современной беллетристике. «Мирская труженица» (По поводу повести В. Крестовского «Семья и школа»). Женское образование. 1880. № 4-5. С. 187-196.

28. Погребная В.Л. Роман Н.Д. Хвощинской «Встреча» в контексте эмансипационного движения Филологические исследования: Международный сборник научных трудов. Вып. 2. Запорожье, Белгород : ЗЮИ МВС Украины, 2003. С. 217-224.

Information about the author: Pogrebnaya V. L., Doctor of Philological Sciences, Professor, Head of the Department of Journalism, «Zaporizhzhia Polytechnic» National University 64, Zhukovskyi str., Zaporizhzhia, 69063, Ukraine 